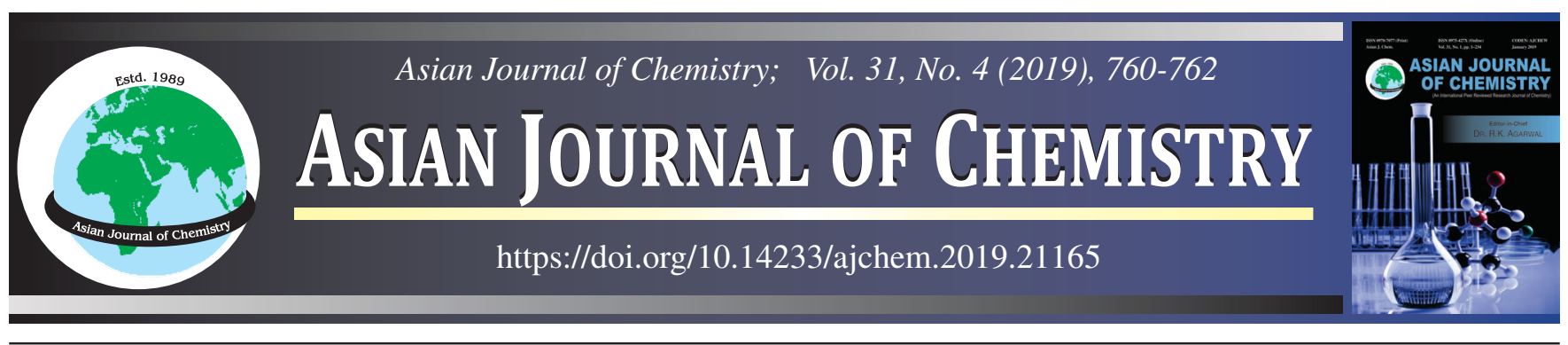

\title{
Synthesis, Characterization and Biological Evaluation of Isoxazoles Derived from 3-Aminoacetophenone
}

\section{T. Raj Kumar ${ }^{1, *}$, S.V. Suresh Kumar ${ }^{2}$ and N. SRINIVASAN ${ }^{3}$}

${ }^{1}$ Department of Pharmaceutical Chemistry, Creative Educational Society's College of Pharmacy, Kurnool- 518218, India

${ }^{2}$ Department of Pharmacognosy, Creative Educational Society's College of Pharmacy, Kurnool-518218, India

${ }^{3}$ Department of Pharmacognosy, Annamalai University, Annamalainagar-608002, India

*Corresponding author: E-mail: rajkutty1983@gmail.com

Isoxazoles were synthesized by condensing different aldehydes with 3-aminoacetophenone coupled to N-methyl piperazines. All the compounds were screened for anticancer activity against human breast cancer cell lines- MCF-7 and MDA-MB-468. The antimycobacterial activity of compounds were assessed against M. tuberculosis using microplate alamar blue assay (MABA). The structures of newly synthesized compounds established on the basis of their m.p., TLC, FTIR, mass and ${ }^{1} \mathrm{H}$ NMR data. The results of antimycobacterial and anticancer studies shows that some of it posses mild to moderate activity against standard. These new synthesized compounds were identified and characterized, demonstrated antitubercular, in vivo efficacy in tumor models like MCF-7 and MDA-MB-468.

Keywords: Isoxazoles, 3-Aminoacetophenone, MCF-7, MDA-MB-468.

\section{INTRODUCTION}

Oxygen-containing heterocyclic building blocks are of great importance in medicinal chemistry and posses antibacterial, antiviral, antifungal, anti-inflammatory, antitubercular, anticancer, insecticidal activities [1-3]. Hence they are used extensively as useful synthons in organic synthesis. In this respect, we envisioned and implemented the synthesis of several novel molecules containing the fused isoxazole skeleton and evaluated their inhibition on cancer cells and tubuerculosis.

In an effort to continually develop potent antitubercular and anticancer agents, a novel series of isoxazoles with piperazine nucleus were synthesized and characterized. These derivatives were tested using estrogen receptor positive breast cancer cell lines MCF-7 and MDA-MB-468.

\section{EXPERIMENTAL}

3-Aminoacetophenone, $\mathrm{N}$-methyl piperazine and other aldehydes derivatives purchased from the SD Fine Chemicals Ltd., Mumbai and were used without further purification. Melting points were determined on a Fisher-Johns Melting Point Apparatus and were uncorrected. Infrared spectra were obtained using KBr Pellet technique on a Bruker IR spectrometer. ${ }^{1} \mathrm{H}$ NMR spectra was obtained on Bruker AV III $500 \mathrm{MHz}$ spectrometer \& Mass spectra obtained from Thermo Scientific MS instrument at the IIT Madras, Chennai. Reaction progress was checked by TLC in a solvent vapour-saturated chamber on glass plates coated with Silica Gel $\mathrm{GF}_{254}$ followed by visualization under UV light (254 nm). The solvent system used for thin layer chromatography was $n$-hexane:ethyl acetate (7:3).

Diazotization and coupling of 3-aminoacetophenone with $\mathrm{N}$-methyl piperazine: $0.01 \mathrm{~mol}$ of 3-Aminoacetophenone in $3 \mathrm{~mL}$ of conc. $\mathrm{HCl} \& 6 \mathrm{~mL}$ water and $1.35 \mathrm{~g}$ of sodium nitrite in $6 \mathrm{~mL}$ of water were prepared separately and both the solutions were placed in ice bath. To this sodium nitrite solution added dropwise with continuous stirring and diazotized. After the completion of diazotization, $\mathrm{N}$-methyl piperazine added to the reaction mixture with continuous stirring at the same temperature i.e., $0-5^{\circ} \mathrm{C}$ and a yellow coloured precipitate is obtained by adding sodium bicarbonate. The product was filtered, washed with ice-cold water and dried.

Synthesis of chalcones: 0.005 mol of Diazotized and coupled product reacted with equimolar amount of aldehydes in a round bottomed flask containing $50 \mathrm{~mL}$ of ethanol. $1 \mathrm{~mL}$

This is an open access journal, and articles are distributed under the terms of the Creative Commons Attribution-NonCommercial-ShareAlike 4.0 (CC BY-NC-SA 4.0) International License which allows readers to freely read, download, copy, distribute, print, search, or link to the full texts of its articles and to use them for any other lawful non-commercial purpose as long as the original source is duly acknowledged. 
of $40 \% \mathrm{KOH}$ added and stirred continuously on magnetic stirrer for $2 \mathrm{~h}$. Completion of the reaction was monitored by TLC. After the completion of the reaction, the reaction mixture was poured into crushed ice and neutralized with dilute $\mathrm{HCl}$. Then the solid is filtered, washed with cold water, dried and recrystallized from ethanol $[4,5]$.

Synthesis of isoxazoles: $0.002 \mathrm{~mol}$ of chalcone derivatives reacted with equimolar hydroxylamine hydrochloride and sodium acetate in $25 \mathrm{~mL}$ ethanol and refluxed for $6 \mathrm{~h}$. The mixture was concentrated and poured into crushed ice and stirred well to obtain the precipitate [6-10]. The precipitate obtained was filtered, washed and recrystallized. TLC solvent system used was $n$-hexane:ethyl acetate (7:3) (Scheme-I).

Anti-TB activity using Alamar blue dye [11]: The anti mycobacterial activity of compounds were assessed against M. tuberculosis using microplate Alamar blue assay (MABA) BACTEC radiometric method and the activity expressed as the minimum inhibitory concentration (MIC) in $\mu \mathrm{g} / \mathrm{mL}$. $M$. tuberculosis (H37 RV strain): ATCC No. 27294 was used for the activity. The standard values are pyrazinamide $3.125 \mu \mathrm{g} / \mathrm{mL}$, streptomycin $6.25 \mu \mathrm{g} / \mathrm{mL}$ and ciprofloxacin $3.125 \mu \mathrm{g} / \mathrm{mL}$.

Anticancer activity by MTT assay method [12]: Cell lines of MCF-7 and MDA-MB-468 were procured from NCCS, Pune. MTT assay was performed based on the procedure given by Dolly and Griffiths [12]. The cell lines were maintained in 96 wells microtiter plate containing MEM media supplemented with $10 \%$ heat inactivated fetal calf serum (FCS), containing $5 \%$ of the mixture of gentamycin $(10 \mu \mathrm{g})$, penicillin $(100 \mathrm{units} / \mathrm{mL})$ and streptomycin $(100 \mu \mathrm{g} / \mathrm{mL})$ in the presence of $5 \% \mathrm{CO}_{2}$ at $37{ }^{\circ} \mathrm{C}$ for $48-72 \mathrm{~h}$.

Cytotoxicity assay: in vitro Growth inhibition effect of test compound was assessed by conversion of MTT into "Formazan blue" by living cells and determined spectrophotometrically. The supernatant from the plate was removed and fresh MEM solution added, treated with different concentrations of compound appropriately diluted with DMSO.

Control group contains only DMSO. 10, 20, 25, 30 and $50 \mu \mathrm{L}$ of the stock solution (10 $\mathrm{mg} / \mathrm{mL}$ prepared in DMSO) were added to respective wells containing $100 \mu \mathrm{L}$ of the medium to make the final concentration of $10,20,25,30$ and $50 \mu \mathrm{g} / \mathrm{mL}$. After $48 \mathrm{~h}$ of incubation at $37{ }^{\circ} \mathrm{C}$ in a humidified atmosphere of $5 \% \mathrm{CO}_{2}$, stock solution of MTT was added to each well ( $20 \mu \mathrm{L}, 5 \mathrm{mg}$ per $\mathrm{mL}$ in sterile PBS) for further $4 \mathrm{~h}$ incubation. The supernatant carefully aspirated, the precipitated crystals of "Formazan blue" were solubilized by adding DMSO (100 $\mu \mathrm{L}$ ) and optical density was measured at wavelength of 570 $\mathrm{nm}$. The results represent the mean of five readings. The concentration at which the OD of treated cells was reduced by $50 \%$ with respect to the untreated control.

$$
\text { Surviving cells }(\%)=\frac{\text { Mean OD of test compound }}{\text { Mean OD at control }} \times 100
$$

1-[(E)-\{3-[3-(4-Chlorophenyl)-1,2-oxazol-5-yl]phenyl\}diazenyl]-4-methylpiperazine (H1): Yellow crystals; yield: $60 \%$; m.p.: $180{ }^{\circ} \mathrm{C}$; m.w. 410.50. TLC 0.66; IR (KBr, $v_{\max }$, $\mathrm{cm}^{-1}$ ): 3417.58 (N-H amine str.), 2924.01-2853.36 (alkyl C-H str.), 1518.75 (aromatic $\mathrm{C}=\mathrm{C}$ bend.); ${ }^{1} \mathrm{H}$ NMR $\left(\mathrm{CDCl}_{3}\right)$ in $\delta$ (ppm): $\delta 8.026-8.219(1 \mathrm{H}, \mathrm{d}, \mathrm{CH}-\mathrm{Ar}) ; \delta 6.532-6.922(8 \mathrm{H}, \mathrm{m}$, Ar-H); $\delta 3.702-3.793\left(3 \mathrm{H}, \mathrm{s}, \mathrm{CH}_{3}\right), \delta\left(2 \mathrm{H}, \mathrm{d}, \mathrm{CH}_{2}\right.$ of isoxazole); Mass: $m / z 383.12[\mathrm{M}+\mathrm{H}]^{+}$. Elemental analysis of $\mathrm{C}_{22} \mathrm{H}_{25} \mathrm{~N}_{5} \mathrm{OCl}$ calcd. (found) \%: C, 63.50 (63.48); H, 5.00 (5.08); Cl, 9.01 (9.34); N, $18.00(18.10)$.

1-[(E)-\{3-[3-(3,4-Dimethoxyphenyl)-1,2-oxazol-5yl]phenyl\}diazenyl]-4-methylpiperazine (H2): Dark brown crystals; yield: $58 \%$; m.p.: $185^{\circ} \mathrm{C}$; m.w. 407.47. TLC 0.74; IR $\left(\mathrm{KBr}, v_{\max }, \mathrm{cm}^{-1}\right): 3461.41$ (N-H amine str.), 2923.41 (carboxylic acid O-H str.), 2852.9 (alkyl C-H str.); ${ }^{1} \mathrm{H}$ NMR $\left(\mathrm{CDCl}_{3}\right.$ ) in $\delta$ (ppm): $\delta 7.963-7.987(1 \mathrm{H} ; \mathrm{d} ; \mathrm{CH}-\mathrm{Ar}) ; \delta 6.836-6.922(8 \mathrm{H}$; $\mathrm{m}, \mathrm{Ar}-\mathrm{H}) ; \delta 3.664-3.711\left(3 \mathrm{H}, \mathrm{s}, \mathrm{CH}_{3}\right) ; \delta 6.533-6.540 \mathrm{~d}(1 \mathrm{H}$, $-\mathrm{CH}=\mathrm{CH}$ ); Mass: $\mathrm{m} / \mathrm{z}, 408.10[\mathrm{M}-\mathrm{H}]^{+}$. Elemental analysis of $\mathrm{C}_{22} \mathrm{H}_{25} \mathrm{~N}_{5} \mathrm{O}_{3}$ calcd. (found) \%: C, 65.49 (65.51); H, 6.08 (6.10); $\mathrm{N}, 17.12$ (17.10).

1-Methyl-4-[(E)-\{3-[3-(4-nitrophenyl)-1,2-oxazol-5yl]phenyl diazenyl]piperazine (H3): Brownish crystals; yield: $62 \%$; m.p.: $170{ }^{\circ} \mathrm{C}$; m.w. 392.41. TLC 0.54; IR (KBr, $v_{\max }, \mathrm{cm}^{-1}$ ): 3417.38 (N-H amine str.), 2923.38, 2853.15 (alkyl C-H str.), 1590.53 (aromatic C=C bend.); ${ }^{1} \mathrm{H}$ NMR $\left(\mathrm{CDCl}_{3}\right)$ in $\delta$ (ppm): $\delta 7.907-8.108(1 \mathrm{H} ; \mathrm{d} ; \mathrm{CH}-\mathrm{Ar}) ; \delta 6.904-6.965(8 \mathrm{H}$;

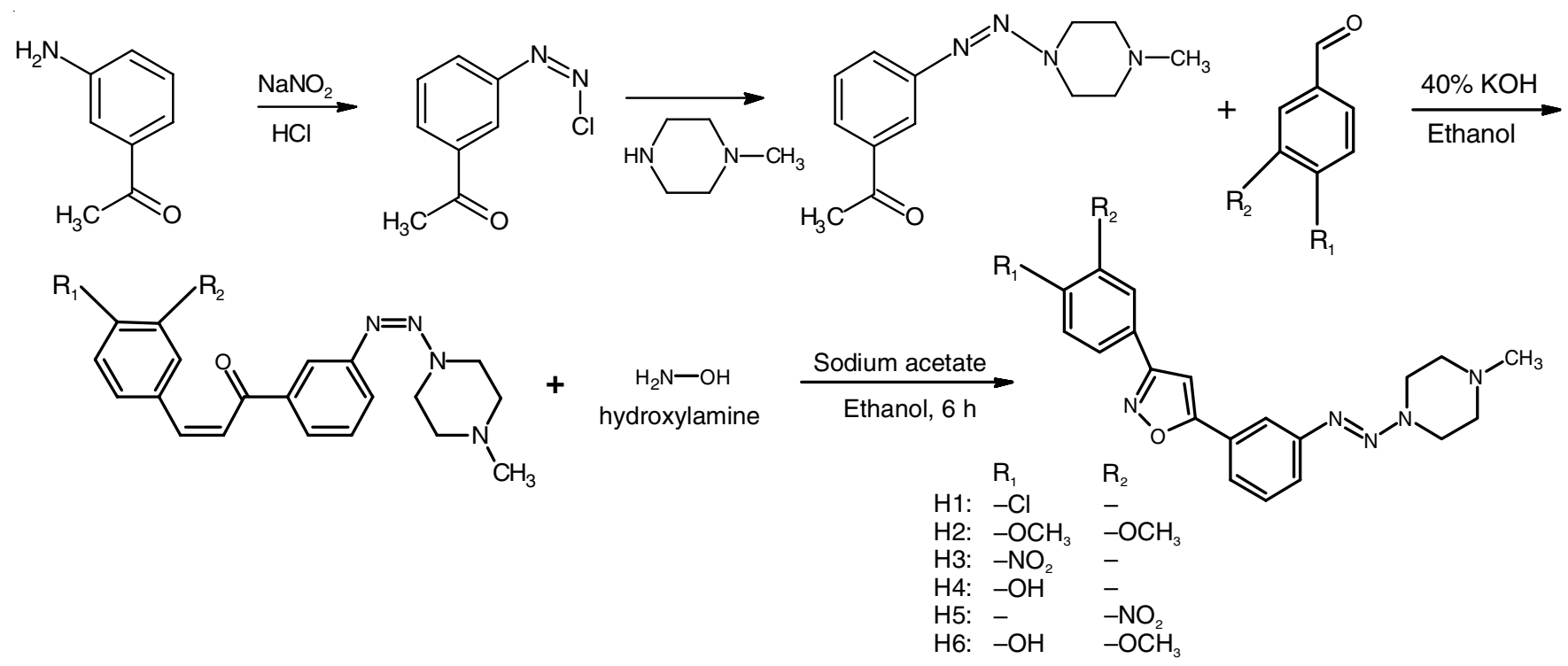


m, Ar-H); $\delta 3.659-3.781\left(3 \mathrm{H}, \mathrm{s}, \mathrm{CH}_{3}\right) ; \delta 6.552 \mathrm{~d}(1 \mathrm{H},-\mathrm{CH}=\mathrm{CH})$; $\delta 5.113\left(1 \mathrm{H}, \mathrm{d}, \mathrm{CH}\right.$ of isoxazole); Mass: $\mathrm{m} / \mathrm{z} 394.32\left(\mathrm{M}^{+}\right)$. Elemental analysis of $\mathrm{C}_{20} \mathrm{H}_{20} \mathrm{~N}_{6} \mathrm{O}_{3}$ calcd. (found) \%: $\mathrm{C}, 61.19$ (61.10); H, 5.08 (5.10); N, 22.12 (22.02).

4-(5-\{3-[(E)-(4-Methylpiperazin-1-yl)diazenyl]phenyl\}1,2-oxazol-3-yl)phenol (H4): Brownish crystals; yield: $66 \%$; m.p.: 17-60 ${ }^{\circ} \mathrm{C}$; m.w. 363.41. TLC 0.69; IR ( $\left.\mathrm{KBr}, v_{\max }, \mathrm{cm}^{-1}\right)$ : 3347.18 (N-H amine str.), 2923.59, 2852.67 (alkyl C-H str.), 1706.38 (aldehyde $\mathrm{C}=\mathrm{O}$ str.); ${ }^{1} \mathrm{H}$ NMR $\left(\mathrm{CDCl}_{3}\right)$ in $\delta$ (ppm): $\delta$ 7.907-8.108 (1H; d; CH-Ar); $\delta$ 6.912-6.916 (8H; m, Ar-H); $\delta$ $3.669\left(3 \mathrm{H}, \mathrm{s}, \mathrm{CH}_{3}\right) ; \delta 6.445 \mathrm{~d}(1 \mathrm{H},-\mathrm{CH}=\mathrm{CH}) ; \delta 9.45(\mathrm{~s}, 1 \mathrm{H}$, $\mathrm{OH}) ; \delta 5.04\left(1 \mathrm{H}, \mathrm{d}, \mathrm{CH}\right.$ of isoxazole); Mass: $m / z 365.23\left(\mathrm{M}^{+}\right)$. Elemental analysis of $\mathrm{C}_{20} \mathrm{H}_{21} \mathrm{~N}_{5} \mathrm{O}_{2}$ calcd. (found) \%: $\mathrm{C}, 66.29$ (66.15); H, 6.12 (6.10); N, 19.35 (19.32).

1-Methyl-4-[(E)-\{3-[3-(3-nitrophenyl)-1,2-oxazol-5-yl]phenyl\}diazenyl]piperazine (H5): Brownish crystals; yield: $58 \%$; m.p.: $175^{\circ} \mathrm{C}$; m.w. 392.41 . TLC 0.55 ; IR $\left(\mathrm{KBr}, v_{\max }, \mathrm{cm}^{-1}\right)$ : 3676.23 (amide $\mathrm{N}-\mathrm{H}$ str.), 3435.24 ( $\mathrm{N}-\mathrm{H}$ amine str.), 2923.69, 2853.40 (alkyl C-H str.), 1525.74 (aromatic $\mathrm{C}=\mathrm{C}$ bend.); ${ }^{1} \mathrm{H}$ NMR $\left(\mathrm{CDCl}_{3}\right)$ in $\delta(\mathrm{ppm}): \delta$ 7.941-8.007 $(1 \mathrm{H} ; \mathrm{d} ; \mathrm{CH}-\mathrm{Ar}) ; \delta$ $7.439(8 \mathrm{H} ; \mathrm{m}, \mathrm{Ar}-\mathrm{H}) ; \delta 3.693-3.733\left(3 \mathrm{H}, \mathrm{s}, \mathrm{CH}_{3}\right) ; \delta 6.890-$ $6.894 \mathrm{~d}(1 \mathrm{H},-\mathrm{CH}=\mathrm{CH}) ; \delta 5.764(1 \mathrm{H}, \mathrm{d}, \mathrm{CH}$ of isoxazole); Mass: $\mathrm{m} / z$ 394.26 $\left(\mathrm{M}^{+}\right)$. Elemental analysis of $\mathrm{C}_{20} \mathrm{H}_{20} \mathrm{~N}_{6} \mathrm{O}_{3}$ calcd. (found) \%: C, 61.56 (61.42); H, 5.17 (5.20); N, 22.23 (22.22).

1-[(E)-\{3-[3-(3-Methoxy-4-hydroxy phenyl)-1,2-oxazol5-yl]phenyl\}diazenyl]-4-methylpiperazine (H6): Brownish crystals; yield: $68 \%$; m.p.: $180{ }^{\circ} \mathrm{C}$; m.w. 393.44. TLC 0.71; IR $\left(\mathrm{KBr}, v_{\max }, \mathrm{cm}^{-1}\right): 3427.62$ (N-H amine str.), 2924.28, 2853.52 (alkyl C-H str.), 1508.72 (aromatic C=C bend.); ${ }^{1} \mathrm{HNMR}\left(\mathrm{CDCl}_{3}\right.$ ) in $\delta$ (ppm): $\delta 7.920-7.940(1 \mathrm{H} ; \mathrm{d} ; \mathrm{CH}-\mathrm{Ar}) ; \delta$ 7.285-7.562 (8H; $\mathrm{m}, \mathrm{Ar}-\mathrm{H}) ; \delta 3.693-3.733\left(3 \mathrm{H}, \mathrm{s}, \mathrm{CH}_{3}\right) ; \delta 6.678-6.708 \mathrm{~d}(1 \mathrm{H}$, $-\mathrm{CH}=\mathrm{CH}) ; \delta 5.802(1 \mathrm{H}, \mathrm{d}, \mathrm{CH}$ of isoxazole $) ; \delta 9.58(\mathrm{~s}, 1 \mathrm{H}, \mathrm{OH})$; Mass: $m / z 395.38\left(\mathbf{M}^{+}\right)$. Elemental analysis of $\mathrm{C}_{21} \mathrm{H}_{23} \mathrm{~N}_{5} \mathrm{O}_{3}$ calcd. (found) \%: C, 64.44 (64.42); H, 6.17 (6.20); N, 18.30 (18.22).

\section{RESULTS AND DISCUSSION}

The novel isoxazoles have been synthesized from the chalcone intermediates. The synthesis of the isoxazole is a three step method. The yields of the synthesized compounds were found to be significant. The synthesized derivatives were undergone physicochemical characterization. The structures of the synthesized compounds was confirmed by IR, mass and ${ }^{1} \mathrm{H}$ NMR. The results obtained from this study confirmed that the product has formed.

The IR spectrum, showed a strong absorption at $1656 \mathrm{~cm}^{-1}$, which is a characteristic band for the carbonyl group of the chalcones. Absorption around $1400 \mathrm{~cm}^{-1}$ was assigned to the $\mathrm{N}=\mathrm{N}$ str. The other $\mathrm{C}=\mathrm{C}, \mathrm{C}-\mathrm{H}, \mathrm{Ar}-\mathrm{H}$ stretching absorptions were noticed in accordance with the structure of synthesized compounds. ${ }^{1} \mathrm{H}$ NMR has shown signal around at $\delta 5$ accounting for isoxazole nucleus. Signal for the aromatic protons were present in between $\delta 8$ and 7. Thus, all the protons were accounted for the respective structures. Mass spectra were also in accordance with the proposed structures.
These isoxazole derivatives have biological activities like antibacterial and anti-inflammatory may be a pave for synthesis and characterization of some new derivatives. All the synthesized compounds were tested for antitubercular activity, the compounds were assessed against $M$. tuberculosis using microplate Alamar blue assay (MABA). All the compounds have mild active against $M$. tuberculosis at $100 \mu \mathrm{g} / \mathrm{mL}$. It also have moderate to good anticancer activity (Table-1). The $\alpha, \beta$ unsaturared part of chalcone along with isoxazole seems to be essential for the activity. But substitution on the phenyl ring decides the extent of potency of the compounds. Compounds with substituent's like chloro, nitro and hydroxyl group at para position and compound with 3-methoxy substituent's $\left(\mathrm{H}_{1}, \mathrm{H}_{2}\right.$, $\mathrm{H}_{3}, \mathrm{H}_{4}$ and $\mathrm{H}_{6}$ ) were cytotoxic against MCF-7 cell lines at $\mathrm{IC}_{50}$ 25-30 $\mu$ g. para Chloro, nitro substituted derivatives $\left(\mathrm{H}_{1}, \mathrm{H}_{3}\right.$, $\mathrm{H}_{5}$ ) were cytotoxic against MDA-MB-468 cell lines at $\mathrm{IC}_{50}$ 30-35 $\mu \mathrm{g}$.

\begin{tabular}{ccc}
\multicolumn{3}{c}{ TABLE-1 } \\
\multicolumn{2}{c}{$\mathrm{IC}_{50}(\mu \mathrm{g})$ OF SYNTHESIZED COMPOUNDS } \\
AGAINST MCF-7 AND MDA-MB-468 \\
\hline \multirow{2}{*}{ Sample code } & $\mathrm{IC}_{50}(\mu \mathrm{g})$ & \\
\cline { 2 - 3 } & $\mathrm{MCF}$ & MDA-MB-468 \\
\hline H1 & $25-30$ & $30-35$ \\
H2 & $25-30$ & 30 \\
H3 & $25-30$ & 30 \\
H4 & $25-30$ & $30-35$ \\
H5 & 20 & 30 \\
H6 & $25-30$ & 30 \\
\hline
\end{tabular}

\section{REFERENCES}

1. J. Kumar, G. Chawla, M. Akhtar, K. Sahu, V. Rathore and S. Sahu, Arabian J. Chem., 10, 141 (2017);

https://doi.org/10.1016/j.arabjc.2013.04.027.

2. K.A. Kumar and P. Jayaroopa, Int. J. Pharm. Chem. Biol. Sci., 3, 294 (2013).

3. C.B. Patil, S.K. Mahajan and S.A. Katti, J. Pharm. Sci. Res., 1, 11 (2009).

4. M.A. Rahman, Chem. Sci. J., 2011, 29 (2011).

5. H. Suwito, Jumina, Mustofa, A.N. Kristanti and N.N.T. Puspaningsih, J. Chem. Pharm. Res., 6, 1076 (2014).

6. G. Thirunarayanan, Org. Chem. Ind. J., 12, 1 (2016).

7. K.C. Gautam and D.P. Singh, Chem. Sci. Trans., 2, 992 (2013); https://doi.org/10.7598/cst2013.478.

8. R Kalirajan, S. Jubie and B. Gowramma, Peertechz J. Med. Chem. Res., 1, 1 (2015).

9. L.S.S. Reddy, M. Bhagavanraju and C. Sridhar, Inventi Impact: Med. Chem., 4, 133 (2015).

10. L.S.S. Reddy, M. Bhagavanraju and C. Sridhar, J. Chem. Pharm. Res., 7, 211 (2015).

11. M.C.S. Lourenço, M,V.N. de Souza, A.C. Pinheiro, M. de L. Ferreira, R.S.B. Gonçalves, T.C.M. Nogueira and M.A. Peralta, ARKIVOC, 181 (2007); https://doi.org/10.3998/ark.5550190.0008.f18.

12. A. Dolly and J.B. Griffiths, Cell and Tissue Culture for Medical Research, John Wiley \& Sons, New York, pp. 62-65 (2000). 